\title{
Heavy Metals Pollution in Water, Sediments and Fish of Léré Lake, Western Mayo Kebbi (Chad)
}

\author{
Tchadanaye New Mahamat ${ }^{1}$, Soledé Kidjakebo ${ }^{2}$, Souvalbé Kandibé Abel ${ }^{2}$, \\ Noumi Guy Bertrand", * \\ ${ }^{1}$ Department of Chemistry, Faculty of Exact and Applied Science, University of N'Djamena, N'Djamena, Chad \\ ${ }^{2}$ Department of Chemistry, Faculty of Science, University of Ngaoundere, Ngaoundere, Cameroon
}

\section{Email address:}

gnoumi@yahoo.fr (N. G. Bertrand)

${ }^{*}$ Corresponding author

\section{To cite this article:}

Tchadanaye New Mahamat, Soledé Kidjakebo, Souvalbé Kandibé Abel, Noumi Guy Bertrand. Heavy Metals Pollution in Water, Sediments and Fish of Léré Lake, Western Mayo Kebbi (Chad). International Journal of Environmental Protection and Policy. Vol. 5, No. 1, 2017, pp. 1-11. doi: 10.11648/j.jjepp.20170501.11

Received: December 21, 2016; Accepted: January 4, 2017; Published: February 17, 2017

\begin{abstract}
The present study is a contribution to the physical and chemical analysis of water, sediments and fish in order to determine the pollution status of Léré lake in Western Mayo-Kebbi (Chad). The study investigates parameters such as temperature, $\mathrm{pH}$, conductivity, turbidity, dissolved oxygen, $\mathrm{BDO} 5$ and $\mathrm{CDO}$. Likewise, concentrations of trace elements known as heavy metals $\mathrm{Cu}, \mathrm{Cd}, \mathrm{Pb}, \mathrm{Fe}, \mathrm{Mn}, \mathrm{As}, \mathrm{Zn}, \mathrm{Ni}$ and $\mathrm{Cr}$ of which some are especially toxic were determined in water, sediments and fish. Results of heavy metals analysis: $\mathrm{Cu}(0.95-3.90 \mathrm{mg} / \mathrm{l}), \mathrm{Pb}(0.13-0.75 \mathrm{mg} / \mathrm{l}), \mathrm{Ni}(0.40-6.40 \mathrm{mg} / \mathrm{l}), \mathrm{Cr}$ (0.03- $0.50 \mathrm{mg} / \mathrm{l}), \mathrm{As}(0.03-0.18 \mathrm{mg} / \mathrm{l}), \mathrm{Cd}(0.07-0.15 \mathrm{mg} / \mathrm{l})$ and $\mathrm{Zn}(0.98-15.30 \mathrm{mg} / \mathrm{l})$ as well as data on CDO (26-50 mg/l) and BDO5 (17-34 mg/l) showed that water pollution of the Léré lake was very significant though consumed by surrounding populations. The same report can be made on strongly contaminated sediments: $\mathrm{Ni}(5.9 \mathrm{mg} / \mathrm{Kg}), \mathrm{As}(2.71 \mathrm{mg} / \mathrm{Kg}), \mathrm{Cr}(6.60$ $\mathrm{mg} / \mathrm{Kg}), \mathrm{Cd}(0.50 \mathrm{mg} / \mathrm{Kg})$ and $\mathrm{Mn}(0.26 \mathrm{mg} / \mathrm{Kg})$. Over all, within the framework of this study, fish flesh was less contaminated than fish gills.
\end{abstract}

Keywords: Physicochemical Parameters, Pollution, Sediment, Fish, Léré Lake

\section{Introduction}

Water resources are essential to all living organisms and the maintenance of environmental properties of the earth [11]. The Appreciation of the surface water quality is based on measurements of physico-chemical parameters and the presence or absence of aquatic organisms and microorganisms which are somewhat indicators of a good quality of water. These data can be supplemented by the analysis of sediments (mud), which constitute a "memory" of river life, notably pollution episodes by heavy metals [12]. The human activity is responsible for the introduction of various pollutants into the environment and particularly into the aquatic environment. Certain pollutants can be biodegradable and vanish with time, whereas others are not, and can persist in, accumulate and become toxic. To deal with this situation, various statutory texts as well at the national level as world, were elaborated having for objectives to limit, decrease, and even remove pollutants considered as toxic. In Chad, there are regulations and texts in regard to the liquid rejections in the natural environment [42]. Indeed, in addition to its scarcity, fresh water is prone to increasing and continuous pressures owing to the industrial development needs, agriculture, and the improvement of life conditions of population and living organisms in aquatic environment. Some chemical elements as heavy metals such as copper, nickel, manganese and iron are essential, but with raised concentrations, they have toxic effects for the living organisms. Other elements such as lead, cadmium, mercury and chromium are not essential to metabolic activities and express primarily toxic properties [10]. Chad relative abound of rivers and lakes which get many advantages to this country. These rivers maintain of water farms, habitations (trade, accommodation) and institutions, while ensuring the 
maintenance of the ground water. It is important to mention that rivers of Chad had full of fish formerly. Nowadays they undergo the risks of climatic changes and become today almost the rubbish dumps [35]. The study subject such as Léré lake is one of the ten lakes of Chad, and the third by its surface. During these last years, different activities increased intensively in the catchment basin of this lake. Indeed, it is liable to demographic pressures, increasing of agricultural activities, fishing and breeding added to the road traffic and climatic changes. The population already starts to worry about the scarcity of certain fish species whose cycle of reproduction could be affected by these previous demonstrations. The high rate of leaching by rainwater has contributed to the sandbank of the lake. A study undertaken in 2011 by the Program of the Information system on the Rural Development and Country planning (P-SIDRAT) showed that the products used for fishing caused a drastic reduction in the quantity and quality of fish. The present work aims at establishing the quality of water, sediments and fish of the Léré lake by the use of physico-chemical analyses. Thus, the physical parameters such as temperature, conductivity, $\mathrm{pH}$, turbidity, dissolved oxygen, CDO (Chemical Demand in Oxygen), BDO5 (Biochemical Demand in Oxygen during five days) as well as the concentrations of certain heavy metals (copper, cadmium, lead, nickel, chromium, arsenic, zinc and manganese) were determined.

\section{Material and Methods}

\subsection{Study Area and Sampling Points}

The Léré lake is located at $9.37^{\circ}$ latitude North and $14.10^{\circ}$ longitude East with an average altitude of $231 \mathrm{~m}$. His depth average is of $6 \mathrm{~m}$ covering a surface of $40.5 \mathrm{~km}^{2}$. Léré town is the capital of the Department of Léré located along the lake at $600 \mathrm{~km}$ in the South of Djamena, the capital of the Chad state. The climate is characterized by two seasons including one dry and one rainy season. Annual rainfalls vary between 400 and $1100 \mathrm{~mm}$. The different sampling points were selected taking into account their accessibility and their proximity of possible sources of pollution. Their geographical distribution is as follows (see figure 1): The upstream point: P1, July (AMO; J) and P4, September (AMO; sept). Located at the entry of the town

The outlet point: P2, July (EXU; J) and P5, September (Exu; sept): Located between the P1 and P3points.

The downstream point: P3, July (AVA; J) and P6, September (AVA; sept)

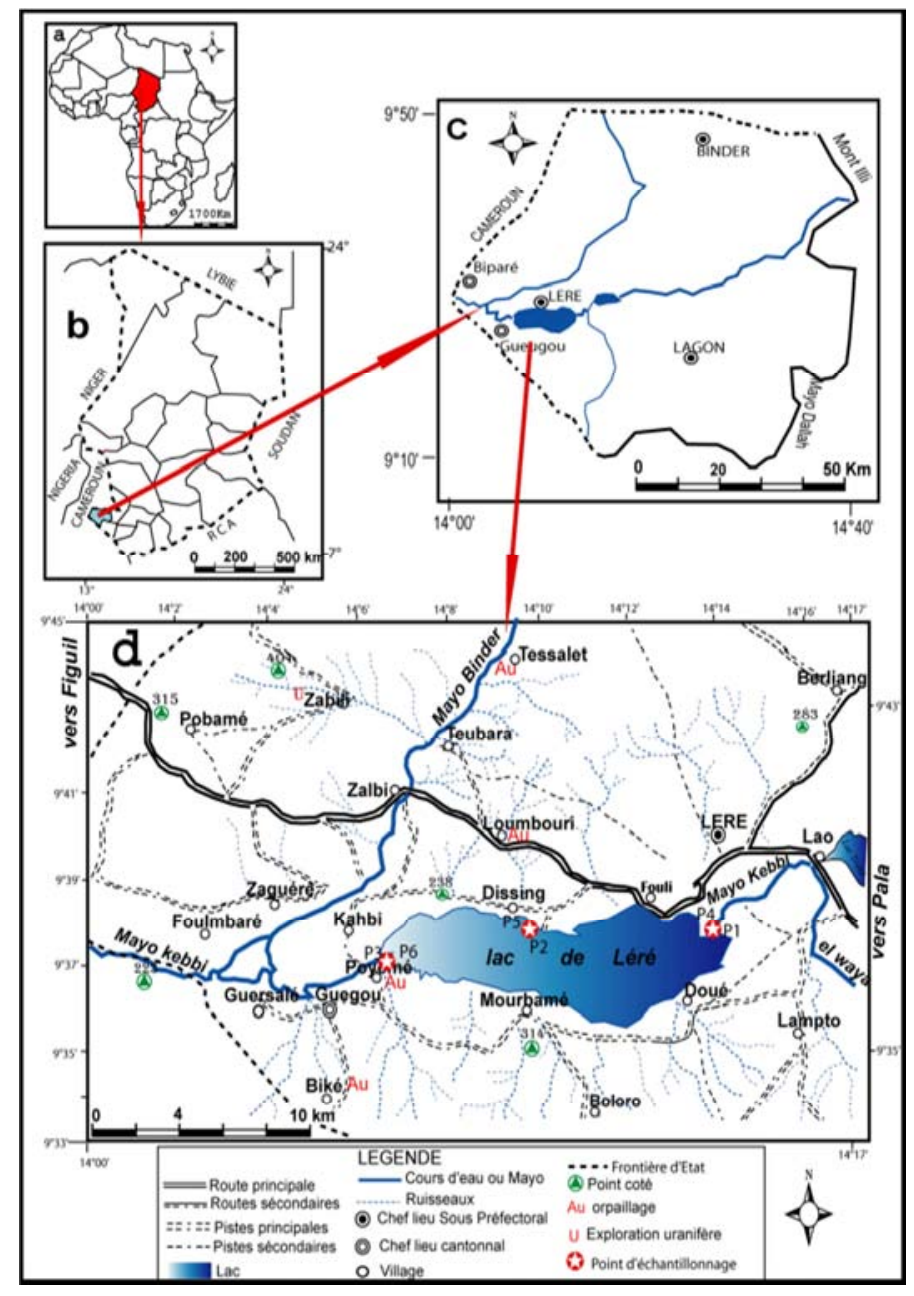

Figure 1. Localisation of the study site. 


\subsection{Taking and Sampling}

Water

Using polypropylene flasks of $250 \mathrm{ml}$ volume, taking of water was carried out by plunging the flask to approximately $50 \mathrm{~cm}$ below the water level. The flasks were previously washed, rinsed to demineralized water, and then with the water of the lake. Three flasks were thus filled with water at each sampling point. Water samples collected were preserved at $4{ }^{\circ} \mathrm{C}$ in icebox and conveyed immediately to the laboratory where they were submitted to a pre-treatment before analysis [44].

\section{Fish}

Fish sampling was done at the edge of Léré Lake on fish coldly sined by fishermen. (Arius latiscutatus) held our attention for the study. It is one of the most captured fish species and the most consumed in the country. These fresh fish were immediately put under ice in icebox and conveyed to the laboratory in Djamena. Once in the laboratory they were immediately weighed, their size measured, and after which they were put at cold storage $4^{\circ} \mathrm{C}$. Thereafter, the fish samples were submitted to the following pretreatment: for each fish, the gills and flesh were separated and introduced into the drying oven, then in the furnace where they were reduced in ash in accordance with the method indicated by [3] and [1]. From ashes were obtained solutions containing heavy metals of which concentration could be determined [44].

\section{Sediments}

The sediments were taken on the three previously cited sites in period of low water level (July) and in period of flood (September). The method consisted to sample surface sediments up to $20 \mathrm{~cm}$ depth using a new shovel (having a plastic sleeve) on board of a barque. The samples were collected in new plastic bags, mixed until obtaining a homogeneous mixture, then preserved in an icebox at $4{ }^{\circ} \mathrm{C}$ and conveyed to the laboratory where they underwent a treatment before analysis [44].

\subsubsection{Material}

Physical measurements of water of Léré lake were done on the evaluation in situ of $\mathrm{pH}$ ( $\mathrm{pH}$-meter ISO SCAN), turbidity (HACH LANGE 2100P ISO), dissolved oxygen (HACH LANGE HQ 30d), temperature and conductivity (multimeter Cyberscan-CON 11). Heavy metals analysis present in water samples, fish and sediments were carried out using UVVisible HACH DR/2400 and SHIMADZU 1700PC spectrophotometers at the Laboratory of Water Resources and Environment (LABEEN) of the University of Djamena.

\subsubsection{Statistical Analysis}

The crude data obtained were subjected to a statistical treatment based on the determination of the precision of measurements (ANOVA). The principal component analysis (PCA) was carried out using XLSTAT 2007 software.

\section{Results and Discussion}

The results of the study are showed in table 1, 2, 3 and 4, and figure 2, 3, 4 and 5

Table 1. Physical parameters of water of the lake.

\begin{tabular}{|c|c|c|c|c|c|c|}
\hline & P1(AMO; J) & P2(EXU; J) & P3(AVA; j) & P4(AMO; sept) & P5(EXU; sept) & P6(AVA; sept) \\
\hline $\mathrm{PH}$ & $(6.91 \pm 0.03)^{\mathrm{a}}$ & $(6.97 \pm 0.01)^{b}$ & $(7.21 \pm 0.01)^{\mathrm{c}}$ & $(7.53 \pm 0.01)^{\mathrm{d}}$ & $(7.92 \pm 0.02)^{\mathrm{f}}$ & $(7.73 \pm 0.02)^{\mathrm{e}}$ \\
\hline $\mathrm{O}_{2}(\mathrm{mg} / \mathrm{l})$ & $(5.5 \pm 0.5)^{\mathrm{ab}}$ & $(6.4 \pm 0.6)^{\mathrm{bc}}$ & $(5.3 \pm 0.4)^{\mathrm{a}}$ & $(5.7 \pm 0.8)^{\mathrm{abc}}$ & $(6.6 \pm 0.4)^{\mathrm{c}}$ & $(5.7 \pm 0.3)^{\mathrm{abc}}$ \\
\hline BDO5 (mg/l) & $(17 \pm 3)^{\mathrm{a}}$ & $(23.6 \pm 0.6)^{b}$ & $(32.2 \pm 0.2)^{\mathrm{c}}$ & $(23 \pm 2)^{b}$ & $(34 \pm 6)^{c}$ & $(26 \pm 1)^{b}$ \\
\hline $\mathrm{CDO}(\mathrm{mg} / \mathrm{l})$ & $(26.46 \pm 0.06)^{\mathrm{a}}$ & $(30.2 \pm 0.2)^{b}$ & $(37.4 \pm 0.4)^{c}$ & $(50 \pm 3)^{d}$ & $(40 \pm 3)^{c}$ & $(27 \pm 2)^{\mathrm{ab}}$ \\
\hline $\mathrm{BDO} 5 / \mathrm{DCO}$ & 0.64 & 0.78 & 0.86 & 0.46 & 0.85 & 0.96 \\
\hline Cond $(\mu \mathrm{S} / \mathrm{Cm})$ & $69.20 \pm 0.60$ & $70.00 \pm 0.03$ & $69.21 \pm 0.02$ & $56.80 \pm 0.80$ & $49.20 \pm 0.00$ & $37.00 \pm 0.40$ \\
\hline
\end{tabular}

Note: For each column, the values followed by the same letter are not significantly different.

\subsection{Physical Parameters of Water}

Physical parameters of water such as temperature, $\mathrm{pH}$, turbidity, conductivity, dissolved oxygen, BDO5 and CDO are given in table 1 and represented on figure 2.

Temperature

The Water temperature of the lake remained almost constant in July (from $29.10 \pm 0.10^{\circ} \mathrm{C}$ to $29.50 \pm 0.10^{\circ} \mathrm{C}$ ) as in September (from $27.20 \pm 0.20^{\circ} \mathrm{C}$ to $27.80 \pm 0.40^{\circ} \mathrm{C}$ ). Some high temperature in July is explained by the sun intensity which causes the water heating prelude to rainfall, whereas in flood period (August-September), the climate was rather wet with less high temperature. So, variations in temperature follow those of climatic conditions [30]. These variations can involve disturbances in the equilibrium of aquatic ecosystem [9].

\section{$p H$}

The $\mathrm{pH}$ values of water in July (from $6.91 \pm 0.03$ to $7.21 \pm 0.01$ ) were almost neutral. On the other hand in September, it can be noted a slight alkalinity (from $7.21 \pm$ 0.01 to $7.53 \pm 0.01$ ), which may be due to the leaching by rain water. These values are comparable with those (7.5) obtained on bays of Port-au-Prince in Haiti [33], in water of Yaoundé lake (6 to 7.7) [27]. The WHO regulation limits the values of $\mathrm{pH}$ from 6.5 to 8.5 . Out of these limits, there can be harmful consequences for fauna and flora [34].

Conductivity

The average values of conductivity ranged between 69.25 \pm 0.56 and $37.00 \pm 0.36 \mu \mathrm{S} / \mathrm{cm}$ showed that water of Léré lake was not very mineralized. It is known that water whose conductivity is between 600 and $1000 \mu \mathrm{S} / \mathrm{cm}$ has a significant 
mineralisation and if it exceeds $1000 \mu \mathrm{S} / \mathrm{cm}$ its mineralisation is considered as excessive (regulation of WHO). Our results are lower than those obtained by [43] for the Chari river, but comparable with those of [21] for the Logone river and finally higher than those obtained for the Congo river $(33 \mu \mathrm{S} / \mathrm{cm})$ by [32].

\section{Turbidity (NTU)}

The turbidity values varied from $(63.13 \pm 1.13)$ NTU to $(89.10 \pm 1.00)$ NTU. This turbidity depended on seasons and time period. The higher turbidity observed in September is not surprising in wet season, because the increase in turbidity results from the phenomenon of leaching by rainwater. The measured average values were higher than the reference value of water quality of 2NTU [31].

Dissolved oxygen

The values obtained $5.34 \pm 0.35 \mathrm{mg} / \mathrm{l}$ and $6.64 \pm 0.32 \mathrm{mg} / \mathrm{l}$ were quite close from a sampling point to another of Léré lake. These values were satisfactory from the ecological point of view. However, they were somewhat lower than those obtained for the Chari [35] and Logone [21] rivers. Generally, the oxygen content must be above $5 \mathrm{mg} / \mathrm{l}$ to be considered as good for the ecosystem [32].

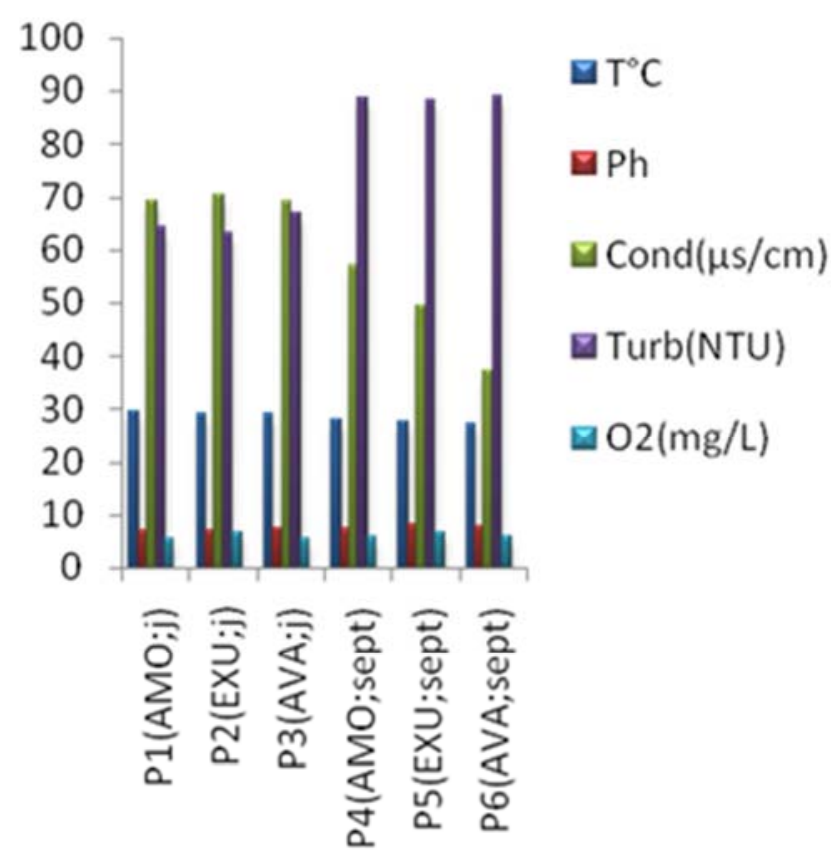

Figure 2. Physical parameters measured in situ.

\section{$C D O$ and $B D O 5$}

The chemical demand in oxygen (CDO) indicates the chemically oxidable quantity of substances, while the biochemical demand in oxygen (BDO5) is the quantity of oxygen that bacteria use to decay partially or completely oxidize organic substances in a water sample in a given time, which is generally five days. Values of CDO are always higher than those of BDO5. Results of table 1 show that data of BDO5 and CDO were in general higher in time of low water level than in wet period. In any case they were so high (BDO5: 17-34 mg/L; CDO: 26-60 mg/L) that we can speculate on an advanced pollution of Léré lake by organic substances. Indeed, the surface water that must be consumed by human should not exceed $5 \mathrm{mg} / \mathrm{L}$ of BDO5 [34].

\subsection{Heavy Metal Concentrations in Water of Léré Lake}

Heavy metal concentrations studied are given in table 2 and represented on figure 3 . The whole samples taken at different points revealed various degree of contamination of lake by heavy metals. Similar data for the Chari River were published by [35]. It can be noted that heavy metal concentrations of water at the outlet point were particularly higher than those of other points, and sometimes widely exceeding the WHO standards [36].

\section{Copper}

The average concentrations of copper by intake point were between $(0.95 \pm 0.01) \mathrm{mg} / \mathrm{l}$ in July and $(3.90 \pm 0.011) \mathrm{mg} / \mathrm{l}$ in September. This content of copper recorded in September was higher than the limit value for the water quality fixed by WHO $(2 \mathrm{mg} / \mathrm{l})$ and would be related to leaching phenomenon by rain. This value was higher than those obtained by [24] for an urban river in Tokyo $(0.22 \mathrm{mg} / \mathrm{l})$ and by [29] for the Niger river $(0.033 \mathrm{mg} / \mathrm{l})$ in Bamako.

Nicke

The nickel concentrations in water of Léré lake varied from $0.40 \pm 0.01 \mathrm{mg} / 1$ to $4.25 \pm 0.02 \mathrm{mg} / \mathrm{l}$ in low water level period and from $2.00 \pm 0.00 \mathrm{mg} / 1$ to $6.40 \pm 0.10 \mathrm{mg} / \mathrm{L}$ in flood period. Nickel is a neurotoxic and highly carcinogen product [13]. The values obtained were higher than those fixed by WHO $(0.05 \mathrm{mg} / \mathrm{l})$.

Arsenic

The results of arsenic varied from $0.03 \pm 0.01$ to $0.18 \pm 0.0$ $\mathrm{mg} / \mathrm{l}$ from a sampling point to another. Raised concentration of arsenic in downstream point of Léré lake can be explained by leaching, consequence of spreading of phosphate fertilizers, herbicides and insecticides in the field around this point. It is perhaps because of that the substance content in water in wet season was more significant than in dry season. Chronic diseases can result from the accumulation of arsenic in human organisms. Its concentration in water should not exceed $0.05 \mathrm{mg} / \mathrm{L}$ (WHO).

\section{Chromium}

Whether the chromium contents were low in July at points P1 (0.03 mg/l) and P3 (0.04 mg/l), it was quite high for other points, mainly in September $(0.10-0.50 \mathrm{mg} / \mathrm{l})$. [21] found relatively high concentrations $(8.667 \mathrm{mg} / \mathrm{l})$ in wastewater of abattoir and $(1.234 \mathrm{mg} / \mathrm{l})$ in wastewater of Chad cotton (Cotton Company of Chad) in Moundou. Wastewater discharges from anthropogenic activities can be a source of pollution by chromium. This element is a carcinogenic substance. The limiting value fixed by WHO is $0.05 \mathrm{mg} / \mathrm{l}$. 
Table 2. Heavy metals content of water of the lake.

\begin{tabular}{|c|c|c|c|c|c|c|}
\hline & P1 (AMO; j) & P2 (EXU; j) & P3 (AVA; j) & P4 (AMO; sept) & P5 (EXU;sept) & P6 (AVA; sept) \\
\hline $\mathrm{Cu}(\mathrm{mg} / \mathrm{l})$ & $(2.20 \pm 0.02)^{\mathrm{d}}$ & $(2.30 \pm 0.01)^{\mathrm{e}}$ & $(0.28 \pm 0.01)^{\mathrm{a}}$ & $(3.90 \pm 0.02)^{\mathrm{f}}$ & $(1.40 \pm 0.02)^{\mathrm{c}}$ & $(0.95 \pm 0.01)^{b}$ \\
\hline $\mathrm{Cd}(\mathrm{mg} / \mathrm{l})$ & $(0.07 \pm 0.01)^{\mathrm{a}}$ & $(0.08 \pm 0.01)^{\mathrm{ab}}$ & $(0.09 \pm 0.01)^{b}$ & $(0.10 \pm 0.01)^{\mathrm{bc}}$ & $(0.12 \pm 0.01)^{\mathrm{e}}$ & $(0.15 \pm 0.01)^{d}$ \\
\hline $\mathrm{Pb}(\mathrm{mg} / \mathrm{l})$ & $(0.13 \pm 0.007)^{\mathrm{a}}$ & $(0.36 \pm 0.13)^{\mathrm{a}}$ & $(0.63 \pm 0.15)^{\mathrm{b}}$ & $(0.70 \pm 0.04)^{\mathrm{b}}$ & $(0.75 \pm 0.03)^{b}$ & $(0.41 \pm 0.02)^{b}$ \\
\hline As $(\mathrm{mg} / \mathrm{l})$ & $(0.05 \pm 0.01)^{\mathrm{ab}}$ & $(0.03 \pm 0.02)^{\mathrm{a}}$ & $(0.18 \pm 0.02)^{d}$ & $(0.10 \pm 0.02)^{\mathrm{c}}$ & $(0.07 \pm 0.02)^{\mathrm{bc}}$ & $(0.15 \pm 0.02)^{d}$ \\
\hline $\operatorname{Mn}(\mathrm{mg} / \mathrm{l})$ & $(0.14 \pm 0.02)^{\mathrm{a}}$ & $(0.5 \pm 0.2)^{\mathrm{b}}$ & $(0.10 \pm 0.00)^{\mathrm{a}}$ & $(0.13 \pm 0.02)^{\mathrm{a}}$ & $(0.40 \pm 0.01)^{\mathrm{b}}$ & $(0.06 \pm 0.02)^{\mathrm{a}}$ \\
\hline $\mathrm{Fe}(\mathrm{mg} / \mathrm{l})$ & $(2.6 \pm 0.3)^{\mathrm{c}}$ & $(2.1 \pm 0.4)^{c}$ & $(2.4 \pm 0.3)^{\mathrm{c}}$ & $(0.13 \pm 0.03)^{\mathrm{a}}$ & $(0.2 \pm 0.1)^{\mathrm{ab}}$ & $(0.6 \pm 0.3)^{\mathrm{b}}$ \\
\hline $\mathrm{Cr}(\mathrm{mg} / \mathrm{l})$ & $(0.03 \pm 0.02)^{\mathrm{a}}$ & $(0.20 \pm 0.01)^{\mathrm{a}}$ & $(0.04 \pm 0.02)^{\mathrm{a}}$ & $(0.5 \pm 0.3)^{b}$ & $(0.18 \pm 0.00)^{\mathrm{a}}$ & $(0.10 \pm 0.02)^{\mathrm{a}}$ \\
\hline
\end{tabular}

Note: For each column, the values followed by the same letter are not significantly different.

\section{Lead}

The average contents of lead varied from $0.13 \pm 0.005 \mathrm{mg} / 1$ to $0.63 \pm 0.01 \mathrm{mg} / 1$ in period of low water level. From $0.70 \pm$ $0.01 \mathrm{mg} / 1$ to $0.75 \pm 0.01 \mathrm{mg} / \mathrm{L}$ in flood period. These results show that lead concentrations were widely higher than those fixed by WHO $(0.05 \mathrm{mg} / \mathrm{l})$. They were in any case higher than those obtained by [44] but lower than the data of [21]. Lead is a toxic element, very dangerous for the human organism. It is difficult to strictly establish the source of this metal in the Léré lake. However, we think that it must come from batteries whose lead is recovered and used in the fishing nets by fishermen. It is also possible that fertilizers used for agriculture are a source of this pollution. Indeed, studies carried out in Canada showed that fertilizers contain up to $3.5 \mathrm{mg} / \mathrm{l}$ of lead [41]. Solid waste and pesticides can also constitute a probable source of lead. Analyses achieved at a large scale on household wastes showed lead content of about $450 \mathrm{mg} / 1$ [41].

Iron

Iron had a distribution similar to manganese. It is also essential for human, but undesirable in water because of some of its properties such as taste, color, task on the clothes. It was enough in all study points but with proportions higher than those of manganese. The highest concentrations were recorded during the low water level. The supply can be of agricultural primarily as well as the leaching of household waste. Iron content of Léré lake widely exceed the value fixed for fresh water: $0.03 \mathrm{mg} / 1$ [37]. The WHO's limit value for iron is $0.30 \mathrm{mg} / \mathrm{l}$.

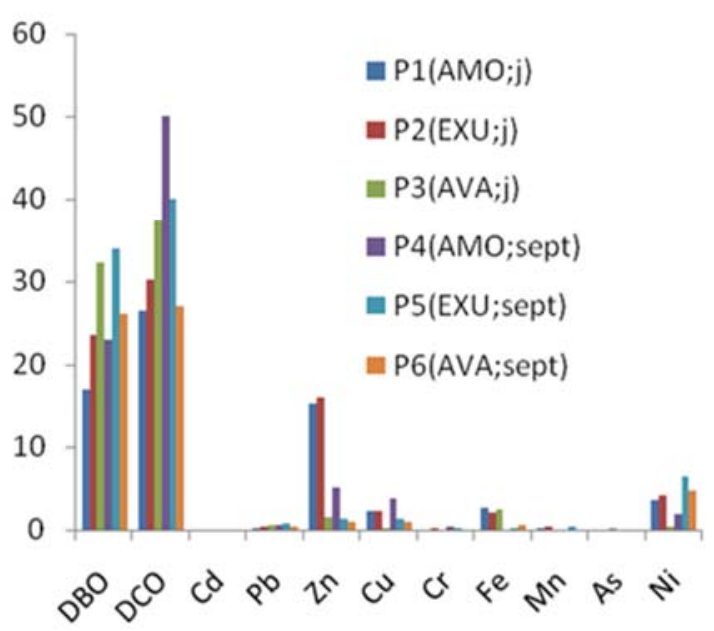

Figure 3. Physico-chemical parameters of water of the lake.

\section{Manganese}

Manganese is an essential metal for the human health. The average concentrations higher than the standard of $0.10 \mathrm{mg} / 1$ (WHO) were recorded in (EXU J): $0.50 \mathrm{mg} / 1$ and (EXU sept): $0.40 \pm 0.01 \mathrm{mg} / \mathrm{l}$. This occurrence of manganese in water does not seem to be only related to household or industrial rejections, because this metal is quite widespread in nature. Indeed, manganese is present enough in vegetable debris [38].

Zinc

The zinc concentrations were higher in period of low water level: $1.60-16.00 \mathrm{mg} / \mathrm{l}$, than in wet season: $0.98-5.2 \mathrm{mg} / \mathrm{l}$. Taking into account the fact that the lake surface considerably increases in rainy season, the zinc supply by leaching is not sufficient to compensate for the reduction in the concentration of this element caused by the phenomenon of dilution. Data obtained were higher than those of [8] for water of Dang lake: $0.19-0.35 \mathrm{mg} / \mathrm{l}$. The Who's limit value is of $3.0 \mathrm{mg} / 1$.

\section{Cadmium}

As the lead and mercury, cadmium is mostly a toxic metal. Whether cadmium contents of $0.007 \pm 0.001$ and $0.009 \pm$ 0.001 obtained in July were somewhat higher than the standard of $0.005 \mathrm{mg} / \mathrm{l}$ (WHO), those obtained in wet period, $0.10 \pm 0.001$ and $0.15 \pm 0.001 \mathrm{mg} / 1$ were higher. These high values can be the result of soil leaching and erosion, which can constitute a source of cadmium. Cadmium pollution is significant in water of Léré lake. Metals analysis carried out on the Fouarat Wadis in Morocco stated cadmium content up to $6.3 \mathrm{mg} / 1,0.25 \mathrm{mg} / \mathrm{l}$ in Bini lake and $0.42 \mathrm{mg} / \mathrm{l}$ in Dang lake in Cameroon [8]. Moreover, $0.40 \mathrm{mg} / \mathrm{l}$ of cadmium was reported in the Nil River, Egypt [17].

\subsubsection{Heavy Metal Contents in Sediments}

Table 3 and figure 4 show the results of heavy metals analysis in sediments of Léré lake. The whole concentrations $(\mathrm{mg} / \mathrm{kg})$ present high values in low water level period, except lead and zinc.

\section{Copper}

As it was mentioned above, results of table 3 indicate that copper contents of $0.94-2.85 \mathrm{mg} / \mathrm{kg}$ in low water level period were more significant than $0.02-0.24 \mathrm{mg} / \mathrm{kg}$ in wet period That could be explained by the covering of old sediments by new supply by the phenomenon of water stream. In all cases, the pollution of sediments by copper remained moderate 
regarding the limit value fixed by WHO $(1 \mathrm{mg} / \mathrm{L})$. [39] report a value of $3.3 \mathrm{mg} / \mathrm{kg}$. The occurrence of copper could be due to the use of fertilizers and phytosanitary products which are the ways of soil enrichment by copper. Our data were lower than those obtained by [7] with $14.77 \mathrm{mg} / \mathrm{kg}$ in sediments of Comoé river (Ivory Coast), [18] with $25.4 \mathrm{mg} / \mathrm{kg}$ in sediments of Rhum el wadis and Saki el Round (Algeria) and [24] with $226.6 \mathrm{mg} / \mathrm{kg}$ in the Tokyo river (Japan).

\section{Lead}

In sediments, the lead contents were sufficiently high, ranging from $0.51 \pm 0.01$ to $0.10 \pm 0.01 \mathrm{mg} / \mathrm{kg}$ in July and from $0.12 \pm 0.02$ to $0.16 \pm 0.02 \mathrm{mg} / \mathrm{kg}$ in September. Such content could be explained by the supply from exhaust gas of vehicles, lead used in nets fishing which failed at the bottom of water. Without forgetting the supply from the discharges of waste water which contributes to raised concentrations of this metal in the sediments of Léré lake.

The results obtained by other authors gave higher lead concentrations than ours. Thereby, the following contents of lead in sediments were published in the literature: $58.4 \mathrm{mg} / \mathrm{kg}$ in the estuary of the Come river, Ivory-Coast [7], $48.8 \mathrm{mg} / \mathrm{kg}$ in estuary bays of Abidjan, Ivory-Coast [4] and $20.30 \mathrm{mg} / \mathrm{kg}$ in sediments of the Mingao River, Cameroon [16].

Nickel

The average contents of this metal were between $2.36 \pm$ $0.06 \mathrm{mg} / \mathrm{kg}$ and $5.90 \pm 0.10 \mathrm{mg} / \mathrm{kg}$ in July, and between $0.4 \pm$ $0.2 \mathrm{mg} / \mathrm{kg}$ and $2.88 \pm 0.02 \mathrm{mg} / \mathrm{kg}$ in September 2014. In all cases the results obtained were higher than the threshold value fixed by WHO $(0.05 \mathrm{mg} / \mathrm{kg})$. The nickel concentrations found were able to disturb the ecological equilibrium of the medium. Higher nickel concentrations $(41 \mathrm{mg} / \mathrm{kg})$ were reported in the Rhum el wadi in Algeria [15].

Table 3. Heavy metals content in sediments.

\begin{tabular}{|c|c|c|c|c|c|c|}
\hline & P1(AMO; j) & P2 (EXU; j) & P3 (AVA; j) & P4 (AMO; sept) & P5(EXU; sept) & P6 (AVA; sept) \\
\hline $\mathrm{Cu}(\mathrm{mg} / \mathrm{kg})$ & $(1.85 \pm 0.05)^{\mathrm{e}}$ & $(2.85 \pm 0.02)^{f}$ & $(0.94 \pm 0.02)^{d}$ & $(0.02 \pm 0.01)^{\mathrm{a}}$ & $(0.16 \pm 0.01)^{b}$ & $(0.24 \pm 0.00)^{\mathrm{c}}$ \\
\hline $\mathrm{Cd}(\mathrm{mg} / \mathrm{kg})$ & $(0.40 \pm 0.03)^{\mathrm{a}}$ & $(0.42 \pm 0.02)^{\mathrm{ab}}$ & $(0.46 \pm 0.06)^{b c}$ & $(0.50 \pm 0.02)^{\mathrm{cd}}$ & $(0.48 \pm 0.02)^{\mathrm{de}}$ & $(0.50 \pm 0.01)^{\mathrm{e}}$ \\
\hline $\mathrm{Pb}(\mathrm{mg} / \mathrm{kg} /)$ & $(0.51 \pm 0.01)^{\mathrm{c}}$ & $(0.10 \pm 0.01)^{\mathrm{a}}$ & $(0.30 \pm 0.10)^{\mathrm{b}}$ & $(0.16 \pm 0.02)^{\mathrm{a}}$ & $(0.12 \pm 0.02)^{\mathrm{a}}$ & $(0.14 \pm 0.00)^{\mathrm{a}}$ \\
\hline $\mathrm{Ni}(\mathrm{mg} / \mathrm{kg})$ & $(5.90 \pm 0.10)^{d}$ & $(2.85 \pm 0.01)^{\mathrm{c}}$ & $(2.36 \pm 0.06)^{b}$ & $(2.88 \pm 0.02)^{c}$ & $(2.35 \pm 0.00)^{b}$ & $(0.40 \pm 0.20)^{\mathrm{a}}$ \\
\hline As $(\mathrm{mg} / \mathrm{kg})$ & $(2.71 \pm 0.01)^{\mathrm{c}}$ & $(3.02 \pm 0.02)^{\mathrm{d}}$ & $(3.41 \pm 0.01)^{\mathrm{e}}$ & $(0.10 \pm 0.02)^{b}$ & $(0.09 \pm 0.01)^{\mathrm{a}}$ & $(0.01 \pm 0.00)^{\mathrm{a}}$ \\
\hline $\mathrm{Cr}(\mathrm{mg} / \mathrm{kg})$ & $(6.60 \pm 0.10)^{d}$ & $(3.50 \pm 0.02)^{b}$ & $(5.70 \pm 0.02)^{\mathrm{c}}$ & $(0.07 \pm 0.01)^{\mathrm{a}}$ & $(0.01 \pm 0.00)^{\mathrm{a}}$ & $(0.02 \pm 0.01)^{\mathrm{a}}$ \\
\hline $\mathrm{Mn}(\mathrm{mg} / \mathrm{kg})$ & $(0.26 \pm 0.02)^{\mathrm{ab}}$ & $(0.30 \pm 0.01)^{b}$ & $(0.30 \pm 0.08)^{b}$ & $(0.40 \pm 0.02)^{\mathrm{c}}$ & $(0.22 \pm 0.02)^{\mathrm{a}}$ & $(0.50 \pm 0.02)^{d}$ \\
\hline $\mathrm{Zn}(\mathrm{mg} / \mathrm{kg})$ & $(0.37 \pm 0.03)^{\mathrm{a}}$ & $(1.50 \pm 0.10)^{\mathrm{c}}$ & $(0.84 \pm 0.03)^{\mathrm{b}}$ & $(2.62 \pm 0.02)^{\mathrm{e}}$ & $(3.37 \pm 0.01)^{d}$ & $(2.36 \pm 0.01)^{d}$ \\
\hline
\end{tabular}

Note: For each column, the values followed by the same letter are not significantly different

\section{Arsenic}

The arsenic contents in sediments were about $0.3 \mathrm{mg} / \mathrm{kg}$ in dry season and $0.1 \mathrm{mg} / \mathrm{kg}$ in rainy season. These average values were higher than the average accepted in sediments of rivers $(0.005 \mathrm{mg} / \mathrm{kg})$. The lower values recorded in wet period could be attributed to soil leaching leading to a certain dilution. The contamination of sediments and water to arsenic could be of human origin by the use of fertilizers, herbicides and insecticides for the market-gardening as well as detergents. A study carried out on the atlantic coast of Nigeria by Ndickwere found a value of $6.2 \mathrm{mg} / \mathrm{kg}$ [10]. In addition a rate of $15.96 \mathrm{mg} / \mathrm{kg}$ for the sediments of estuary bays of Abidjan in Ivory-Coast was reported [4].

\section{Chromium}

The analysis of sediments exhibited results from $3.50 \pm$ 0.02 to $6.60 \pm 0.10 \mathrm{mg}$ of chromium per $\mathrm{kg}$ of sediments for the month of July, thus showing an advanced pollution. Nevertheless, higher published concentrations of chromium were for Turkey lakes from 0.08 to $6.41 \mathrm{mg}$ of chromium per $\mathrm{g}$ of sediments [15].

Manganese

The manganese rates in sediments were from $0.30 \pm 0.01$ to $0.26 \pm 0.02 \mathrm{mg} / \mathrm{kg}$ in time of low water level and from $0.22 \pm$ 0.02 to $0.50 \pm 0.02 \mathrm{mg} / \mathrm{kg}$ in September. These concentrations were quite lower compared to those obtained by other authors: $255 \mathrm{mg} / \mathrm{kg}$ [19], 125mg/kg [16] and $131.95 \mathrm{mg} / \mathrm{kg}$ [7].

Iron

The highest concentration of iron in sediments was of 2.64 $\mathrm{mg} / \mathrm{kg}$ which was widely below the standard of WHO (7 $\mathrm{mg} / \mathrm{kg}$ ). Moreover, we can say that this metal does not contribute to the pollution of sediments of the lake. The occurrence of iron is related to the structure of silicates which belong to the main Components of these sediments [20].

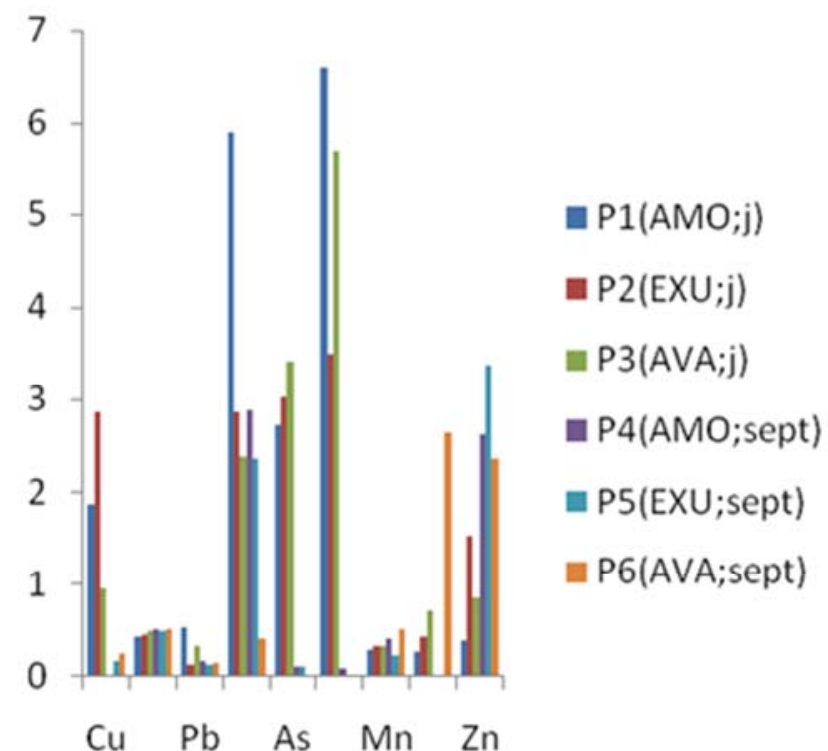

Figure 4. Heavy metals content in sediments.

Zinc

The highest values of zinc rate were observed in wet season $(3.37 \mathrm{mg} / \mathrm{kg})$. This significant zinc supply could be the result of wastewater of the city, household waste, as well 
as fertilizers used in farms.

\section{Cadmium}

The results of metal analysis in sediments showed that cadmium rates in the various sampling points of the lake were higher in flood period with concentration of $0.48 \pm 0.02$ $\mathrm{mg} / \mathrm{kg}$ compared to the low water level period with concentrations varying between 0.40 and $0.46 \mathrm{mg} / \mathrm{kg}$ in down stream. These results let us presume that the cause of raised contents in wet period could be due to the running water involving enough quantity of mud in the lake. A study of [24] on water and sediments of an urban river in Tokyo made case of a cadmium content of $0.9 \mathrm{mg} / \mathrm{kg}$.

\subsubsection{Heavy Metal Concentrations in Fish}

The results of physico-chemical analysis of fish are given in table 4 and are represented on figure 5. These data highlighted a significant contamination of fish by heavy metals by accumulation following the consumption of water, planktons, muds, grasses etc. in certain fish samples, gills were more contaminated than flesh while in others, it was rather the opposite. This contamination seems to be of randomness while certain fish were severely contaminated than others. Taking into account the fact that these fish are consumed by the population, it is necessary to be worried.

Copper
The copper concentrations appeared higher in the gills than in the flesh. The average values of concentrations were 0.54 $0.44 \mathrm{mg} / \mathrm{kg}$ and $0.20-0.35 \mathrm{mg} / \mathrm{kg}$ respectively in the gills and flesh.

Other researchers found values more raised: $2.9 \mathrm{mg} / \mathrm{kg}$ in the Harbestport Dam Lake in South Africa [19] and $12 \mathrm{mg} / \mathrm{kg}$ in Bay of Abou-Kir in Egypt [40].

Lead

For the two parts of fish analyzed during the two sampling, the lead concentrations were: 0.16 and $0.14 \mathrm{mg} / \mathrm{kg}$ in the gills, and 0.50 and $0.27 \mathrm{mg} / \mathrm{kg}$ in the flesh. These values were higher than those fixed by WHO $(0.20 \mu \mathrm{g} / \mathrm{g})$. In water of the Harbestport lake in South Africa, [19] found a lead content of $0.42 \mathrm{mg} / \mathrm{kg}$ in fish. A comparable rate of 0.48 $\mathrm{mg} / \mathrm{kg}$ was also reported by [25] for fish of the delta of Niger in Nigeria.

Arsenic

The average rates in arsenic were: 0.06 and $0.18 \mathrm{mg} / \mathrm{kg}$ for the gills, whereas for the flesh, they were 0.03 and 0.14 $\mathrm{mg} / \mathrm{kg}$. These data were lower than the limit value $(5 \mathrm{mg} / \mathrm{kg})$. In the same way, they were lower than those of [19] who found 0.36 and $0.28 \mathrm{mg} / \mathrm{kg}$ respectively for the Nakuru and Mellwaine lakes in South Africa. Afterwards of $3.5 \mathrm{mg} / \mathrm{kg}$ for fish of North Canada lakes [14].

Table 4. Heavy metals Content ( $\mathrm{mg} / \mathrm{kg}$ ) in fish.

\begin{tabular}{lllll}
\hline & P1 (gills; jul) & P2 (flesh; jul) & P3 (gills; sept) & P4 (flesh; sept) \\
\hline $\mathrm{Cu} \mathrm{mg} / \mathrm{kg})$ & $(0.54 \pm 0.02)^{\mathrm{d}}$ & $(0.20 \pm 0.03)^{\mathrm{a}}$ & $(0.44 \pm 0.04)^{\mathrm{c}}$ & $(0.34 \pm 0.02)^{\mathrm{b}}$ \\
$\mathrm{Cd}(\mathrm{mg} / \mathrm{kg})$ & $(0.31 \pm 0.01)^{\mathrm{a}}$ & $(0.42 \pm 0.02)^{\mathrm{b}}$ & $(0.55 \pm 0.01)^{\mathrm{c}}$ & $(0.72 \pm 0.02)^{\mathrm{d}}$ \\
$\mathrm{Pb}(\mathrm{mg} / \mathrm{kg})$ & $(0.16 \pm 0.06)^{\mathrm{a}}$ & $(0.5 \pm 0.02)^{\mathrm{b}}$ & $(0.14 \pm 0.04)^{\mathrm{a}}$ & $(0.27 \pm 0.03) \mathrm{a}$ \\
$\mathrm{Ni}(\mathrm{mg} / \mathrm{kg})$ & $(0.10 \pm 0.04)^{\mathrm{b}}$ & $(0.00 \pm 0.00)^{\mathrm{a}}$ & $(2.40 \pm 0.02)^{\mathrm{d}}$ & $(0.56 \pm 0.02)^{\mathrm{c}}$ \\
$\mathrm{As}(\mathrm{mg} / \mathrm{kg})$ & $(0.06 \pm 0.02)^{\mathrm{a}}$ & $(0.03 \pm 0.02)^{\mathrm{a}}$ & $(0.18 \pm 0.02)^{\mathrm{c}}$ & $(0.14 \pm 0.02)^{\mathrm{b}}$ \\
$\mathrm{Cr}(\mathrm{mg} / \mathrm{kg})$ & $(0.07 \pm 0.02)^{\mathrm{a}}$ & $(0.05 \pm 0.00)^{\mathrm{a}}$ & $(0.18 \pm 0.02)^{\mathrm{c}}$ & $(0.14 \pm 0.06)^{\mathrm{b}}$ \\
$\mathrm{Mn}(\mathrm{mg} / \mathrm{kg})$ & $(0.80 \pm 0.04)^{\mathrm{c}}$ & $(0.2 \pm 0.02)^{\mathrm{a}}$ & $(0.60 \pm 0.02)^{\mathrm{b}}$ & $(0.03 \pm 0.01)^{\mathrm{a}}$ \\
$\mathrm{Fe}(\mathrm{mg} / \mathrm{kg})$ & $(0.30 \pm 0.02)^{\mathrm{b}}$ & $(0.05 \pm 0.02)^{\mathrm{a}}$ & $(2.5 \pm 0.2)^{\mathrm{d}}$ & $(1.15 \pm 0.03)^{\mathrm{c}}$ \\
$\mathrm{Zn} \mathrm{(mg/kg)}$ & $(1.2 \pm 0.2)^{\mathrm{b}}$ & $(0.5 \pm 0.4)^{\mathrm{a}}$ & $(3.1 \pm 0.1)^{\mathrm{d}}$ & $(2.4 \pm 0.3)^{\mathrm{c}}$ \\
\hline
\end{tabular}

Note:For each column, the values followed by the same letter are not significantly different.

Nickel

The average contents of this metal were more significant in the gills than in the flesh where sometimes they were negligible

\section{Chromium}

In the two parts (gills and flesh) of analyzed fish, all the samples exhibited chromium concentrations $(0.05-0.18$ $\mathrm{mg} / \mathrm{kg}$ ) higher than the FAO/WHO threshold of $0.015 \mathrm{mg} / \mathrm{kg}$ [26]

\section{Manganese}

The manganese contents varied from 0.60 to $0.80 \mathrm{mg} / \mathrm{kg}$ and from 0.03 to $0.20 \mathrm{mg} / \mathrm{kg}$ in the gills and flesh respectively. In all cases, these average concentrations were lower than the limit value of FAO/WHO (2 mg/kg).Our results were comparable with those obtained by [10] with $0.63 \mathrm{mg} / \mathrm{kg}$ in the Kpong basin in Ghana, but lower than those of [25] with $1.1 \mathrm{mg} / \mathrm{kg}$ in the Niger delta in Nigeria and [19] with $12 \mathrm{mg} / \mathrm{kg}$ in the South Africa lakes.

\section{Iron}

The results showed an iron occurrence in the gills with $0.30-2.5 \mathrm{mg} / \mathrm{kg}$, higher than those found in the flesh with $0.05-1.15 \mathrm{mg} / \mathrm{kg}$. However, these values were below the WHO's threshold (7 mg/kg).

Other results were exposed in the literature: $33 \mathrm{mg} / \mathrm{kg}$ for the Tanganyika lake [19], $11.2 \mathrm{mg} / \mathrm{kg}$ for the Mariout lake in Egypt [40], $3.8 \mathrm{mg} / \mathrm{kg}$ for the Kpong basin in Ghana [10], $4.65 \mathrm{mg} / \mathrm{kg}$ for the Victoria lake in Kenya [45] and6.53 $\mathrm{mg} / \mathrm{kg}$ for the Logone river in Chad [44].

\section{Zinc}

During flood period, zinc content in the gills $(3.1 \mathrm{mg} / \mathrm{kg})$ as in the flesh $(2.4 \mathrm{mg} / \mathrm{kg})$ was comparable with that of the sediments, but higher than the FAO/WHO threshold value (2 $\mathrm{mg} / \mathrm{kg}$ ). More significant zinc contents in fish were published: $120 \mathrm{mg} / \mathrm{kg}$ in Harbestport lake in South Africa [19]. 


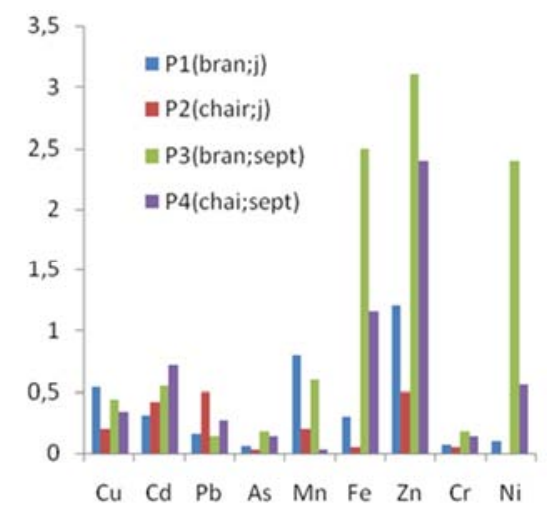

Figure 5. Heavy metals Content in fish.

\section{Cadmium}

Results of analysis of cadmium contents in the gills and flesh were between $0.31-0.55 \mathrm{mg} / \mathrm{kg}$ and $0.42-0.72 \mathrm{mg} / \mathrm{kg}$ respectively. These contents were very high than the FAO/WHO threshold value which is of $0.05 \mathrm{mg} / \mathrm{kg}$. Cadmium which is a highly toxic metal can be harmful for the human health by the abusive consumption of these fish. The cadmium concentrations obtained were comparable with the data of Kayalto (2008) from the study of Chari water in Chad. But these concentrations were higher than those published by other authors: $0.02 \mathrm{mg} / \mathrm{kg}$ in the Iskenderun bay in Turkey [6] and $0.009 \mathrm{mg} / \mathrm{kg}$ in the Kassumigura lake in Japan [2].

\section{Principal Component Analysis (PCA)}

To get better representation of data (variables), we used factual techniques of reduction of dimensions by applying the method of principal components analysis (PCA) to the whole data.

\subsection{Analysis of Water Samples}

The PCA results of water are given in table 5 . The first two columns of this table allow make up of figure 6 from which it arises a satisfactory representation of variables. It can be noted that the last three columns were not used because two dimensions were enough to interpret the analysis as the two factors F1 and F2, add up a variance of almost $68 \%$.

The principal component F1 (44\%) was positively correlated with the majority of variables: $\mathrm{pH}$, Turbidity, $\mathrm{CDO}$, BDO5, oxygen, arsenic, cadmium, lead, chromium and nickel, and negatively with: iron, zinc, manganese, copper and conductivity. It must be noted that the majority of these variables significantly contributed to the pollution of Léré lake (negative correlations).

The F2 axis is an opposition axis between metals such as $\mathrm{Fe}$, As and $\mathrm{Cd}$ (positive correlations) on one hand, and $\mathrm{Zn}$, $\mathrm{Mn}, \mathrm{Cu}, \mathrm{Ni}, \mathrm{Cr}$ and $\mathrm{Pb}$ (negative correlations) on the other.

\subsection{Principal Component Analysis of Sediments}

The results of principal component analysis of sediments of Léré lake are given in table 6. Here F1 and F2 factors account for $82.32 \%$ of total variance.

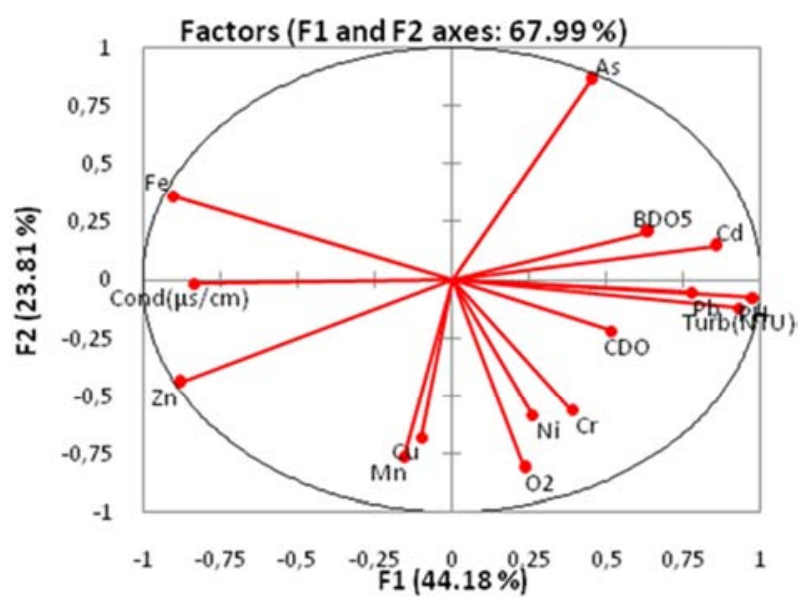

Figure 6. Circle of correlations (water samples).

Table 5. Correlations between variables and factors.

\begin{tabular}{llllll}
\hline & F1 & F2 & F3 & F4 & F5 \\
\hline $\mathrm{PH}$ & 0.977 & -0.078 & -0.155 & -0.031 & -0.123 \\
$\mathrm{Cond}(\mu \mathrm{s} / \mathrm{cm})$ & -0.836 & -0.015 & 0.331 & 0.433 & -0.060 \\
Turbo(NTU) & 0.930 & -0.121 & 0.084 & -0.333 & -0.045 \\
$\mathrm{O} 2$ & 0.236 & -0.813 & -0.421 & 0.318 & 0.078 \\
$\mathrm{BDO} 5$ & 0.637 & 0.205 & -0.215 & 0.712 & -0.002 \\
$\mathrm{CDO}$ & 0.516 & -0.221 & 0.756 & 0.311 & -0.128 \\
$\mathrm{Cu}$ & -0.097 & -0.679 & 0.631 & -0.364 & -0.008 \\
$\mathrm{Cd}$ & 0.854 & 0.145 & -0.366 & -0.281 & 0.191 \\
$\mathrm{~Pb}$ & 0.776 & -0.054 & 0.344 & 0.525 & -0.026 \\
$\mathrm{Ni}$ & 0.261 & -0.586 & -0.729 & -0.181 & -0.157 \\
$\mathrm{As}$ & 0.452 & 0.863 & 0.150 & 0.058 & 0.160 \\
$\mathrm{Mn}$ & -0.156 & -0.765 & -0.322 & 0.513 & 0.153 \\
$\mathrm{Fe}$ & -0.904 & 0.360 & -0.111 & 0.202 & 0.010 \\
$\mathrm{Zn}$ & -0.881 & -0.444 & -0.004 & -0.155 & 0.061 \\
$\mathrm{Cr}$ & 0.388 & -0.561 & 0.698 & -0.110 & 0.187 \\
\hline
\end{tabular}

Table 6. Correlations between variables and factors

\begin{tabular}{llllll}
\hline & F1 & F2 & F3 & F4 & F5 \\
\hline $\mathrm{Cu}$ & 0.771 & 0.166 & -0.558 & 0.257 & 0.006 \\
$\mathrm{Cd}$ & -0.944 & -0.013 & 0.188 & -0.223 & 0.154 \\
$\mathrm{~Pb}$ & 0.752 & 0.138 & 0.637 & 0.011 & -0.096 \\
$\mathrm{Ni}$ & 0.831 & -0.339 & 0.316 & 0.303 & 0.062 \\
$\mathrm{As}$ & 0.880 & 0.245 & -0.267 & -0.285 & 0.118 \\
$\mathrm{Cr}$ & 0.948 & 0.234 & 0.088 & -0.199 & 0.009 \\
$\mathrm{Mn}$ & -0.624 & 0.671 & 0.129 & 0.244 & 0.291 \\
$\mathrm{Fe}$ & -0.450 & 0.844 & 0.019 & 0.045 & -0.289 \\
$\mathrm{Zn}$ & -0.870 & -0.458 & -0.124 & 0.066 & -0.115 \\
\hline
\end{tabular}

Variables from figure 7 are well represented. The F1 factor divides metals into two opposite groups: on one side arsenic, chromium, copper, lead and nickel (strong positive correlations), and the other, zinc, manganese, cadmium and iron (very strong negative correlations). These metals have an essential contribution in the contamination of sediments. For instance, arsenic, chromium, copper and lead come from the same source which can be agricultural. 


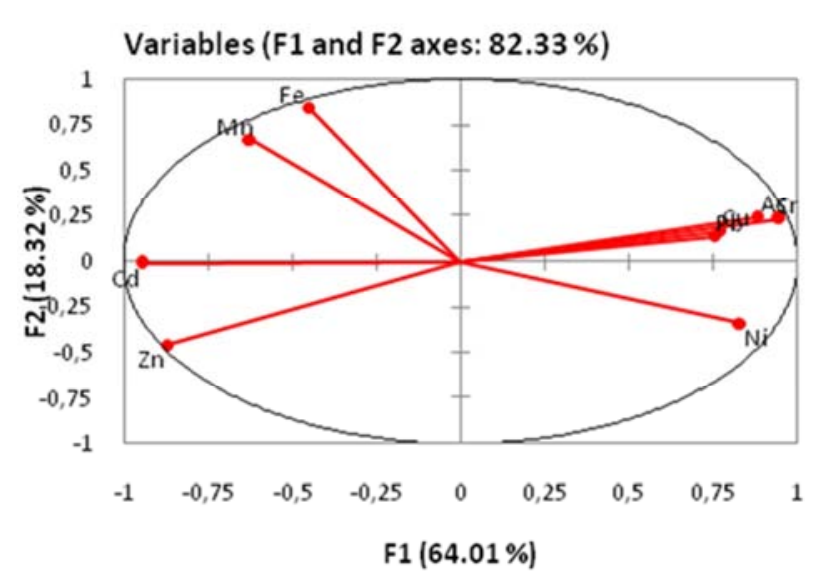

Figure 7. Circle of correlations (sediments).

\subsection{Principal Component Analysis of Fish}

The analysis done from fish samples (table 7 and figure 8) show that the two components F1 and F2 have a total variance of $90.54 \%$.

Table 7. Correlations between variables and factors for fish samples.

\begin{tabular}{llll}
\hline & F1 & F2 & F3 \\
\hline $\mathrm{PH}$ & -0.271 & 0.790 & 0.550 \\
$\mathrm{Cu}$ & 0.418 & 0.775 & -0.474 \\
$\mathrm{Cd}$ & 0.617 & -0.777 & -0.126 \\
$\mathrm{~Pb}$ & -0.725 & -0.578 & 0.375 \\
$\mathrm{Ni}$ & 0.890 & 0.149 & 0.431 \\
$\mathrm{As}$ & 0.992 & -0.125 & 0.016 \\
$\mathrm{Cr}$ & 0.989 & -0.129 & 0.070 \\
$\mathrm{Mn}$ & 0.113 & 0.994 & -0.010 \\
$\mathrm{Fe}$ & 0.964 & 0.025 & 0.265 \\
$\mathrm{Zn}$ & 0.997 & -0.067 & -0.025 \\
\hline
\end{tabular}

We can see from figure 8 that variables are well represented. This reveals that all metals (except lead) are positively correlated with the F1 axis and most of them are from the same origin (water, sediments...).

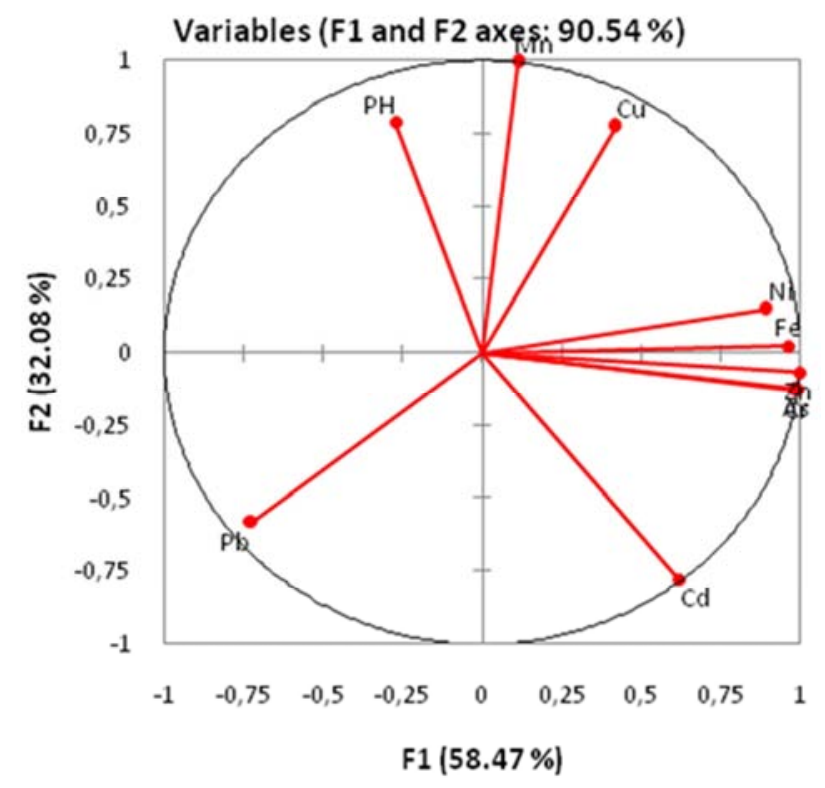

Figure 8. Circle of correlations (fish).

\section{Conclusion}

Work that we undertook at the edge of Léré lake enabled us to determine heavy metal contents (harmful for health) in water, sediments and fish at various points and seasons.

Results of heavy metal analyses: $\mathrm{Cu}(0.95-3.90 \mathrm{mg} / \mathrm{L})$, $\mathrm{Pb}$ (0.13-0.75 mg/l), Ni (0.40-6.40 mg/l), Cr (0.03-0.50 $\mathrm{mg} / \mathrm{l})$, As (0.03-0.18 mg/l), Cd (0.07-0.15 mg/l) and $\mathrm{Zn}$ $(0.98-15.30 \mathrm{mg} / \mathrm{l})$ as well as data of CDO $(26-50 \mathrm{mg} / \mathrm{l})$ and BDO5 (17-34 mg/l) are widely above WHO's standards, and show that water pollution of Léré lake though consumed by surrounding populations is very significant.

The same report can be made from strongly contaminated sediments: Ni $(5.9 \mathrm{mg} / \mathrm{kg})$, As $(2.71 \mathrm{mg} / \mathrm{kg}), \mathrm{Cr}(6.60$ $\mathrm{mg} / \mathrm{kg}), \mathrm{Cd}(0.50 \mathrm{mg} / \mathrm{kg})$ and $\mathrm{Mn}(0.26 \mathrm{mg} / \mathrm{kg})$.

Fish are known as bioaccumulators of micro pollutants. With regard to this, may be taking into account the age and weight of young fish, the concentration of heavy metals in the gills $(\mathrm{Cu}: 0.54 \mathrm{mg} / \mathrm{kg}$, Ni: $0.10 \mathrm{mg} / \mathrm{kg}, \mathrm{Fe}: 0.30 \mathrm{mg} / \mathrm{kg}$ and Cd: $0.55 \mathrm{mg} / \mathrm{kg})$ is more significant than in the flesh $(\mathrm{Cu}$ : $0.20 \mathrm{mg} / \mathrm{kg}, \mathrm{Ni}: 0.00 \mathrm{mg} / \mathrm{kg}, \mathrm{Fe}: 0.05 \mathrm{mg} / \mathrm{kg}$ and $\mathrm{Cd}: 0.72$ $\mathrm{mg} / \mathrm{kg}$ ). Cadmium made the exception.

As no industrial activities is realized around the Léré lake, we think that agriculture, fishing, breeding, rainwater and urban wastewater are the main causes of advanced pollution of water, sediments and fish of this lake.

\section{References}

[1] AFNOR. (1994). Qualités des sols. AFNOR Edition, 250p.

[2] Alam, M. G. M., Tanaka, A., Allinson, G., Laurenson, L. J. B., Stagnitti, F., and Snow, E. T., (2002). A comparison of trace element concentrations in cultured and wild carp (Cyprinus carpio) of Lake Kasumigaura, Japan. Ecotox. Environ. Safe., 53: $348-354$.

[3] AOAC (1990). Official Methods of analysis, 15 the edition. Association of official analytical chemists, Washington. D. C.

[4] Aoua S. Coulibaly, Sylvain Monde, Valérie A. Wognin et Kouamé Aka (2009). Analysis of trace metal elements in bais estuaries of Abidjan in Côte d'Ivoire. Africa science 05 (3) 7796.

[5] B. Katemo Manda, G. Golinet, L. André, A. Choka Manda, J. P. Marquet \& J. C. Micha (2010). Evaluation of contamination of the tropical string with elements traces in the basins of the superior Lufira (Katanga/DRC Congo).

[6] Aysun Türkmen, Mustafa Türkmen, Yalçın Tepe, İhsan Akyurt. (2005). Heavy metals in three commercially valuable fish species from Iskenderun Bay,Northern East Mediterranean Sea, Turkey. Food Chemistry, Volume 91, Issue 1, June 2005, Pages 167-172.

[7] Keiba N K, Siaka Barthélémy B, Gbombélé S,Nagnin S, Bernard, Soro M et Jean B. (2013). Concentration of heavy metals in sediments of the estuary of the river Comoé in Grand Bassam (Ivory Coast South east). Journal of Applied Biosciences 61: 4530-4539 ISSN 1997-5902. 
[8] Barkaï Oumar, Nga Leopol Ekengelé et Ondoa Augustin Balla (2014). Assessment of level of pollution by heavy metals in Lakes Bini and Dang, the Adamaoua Region, Cameroon $\mathrm{http}: / /$ www.afrique science.info.

[9] Bremond R. et Vuichard R. (1973). The water quality parameters. Department of protection of nature and the environment, 179.

[10] Biney, C., Amuzu, A. T., Calamari, D., Kaba, N., Mbome, I. L., Naeve, H., Ochumba,P. B. O., Osibanjo,O.,Radegonde, V. \&Saad, M. A. H. (1994). Review of heavy metals in the African Aquatic Environment. Ecotoxicology and Environmental Safety 28: 134-159.

[11] Christian N. et Alain R. (2000). Déchets, effluents et pollution. Impact sur l'environnement et la santé. $2^{\mathrm{e}}$ edition DUNOD, $108 \mathrm{p}$.

[12] De Villers Julliette, Squilben Marianne, Yourassou Wsky Catherine (2005). Quality physicochemical and chemical surface waters (IBGE).

[13] Das K. K., Das S. N. et Dhundasi S. A. (2008). Nickel, its adverse healt effect and oxidative stress. India J. of Med. Res. $128 \mathrm{pp} 412-425$.

[14] Denis Laliberté \& Gaby Tremblay (2002). Levels of metals, $\mathrm{PCB}$ and dioxins and Furan in fish and sediments from four lakes in Northern Quebec in the Canada.

[15] Durali Mendil, Ozzur D. U. (2007). Determination of trace metal levels in sediments and five fish species from lake in Tokat, Turkey. Food chemistry, volume 101, Issue 2: 739-745.

[16] Ekengelé Nga Leopold; Myung Chac Jung, Ombolo Auguste, Ngounou Ngatcha; Ekodeck Georges; MbomeLape (2008). Metals pollution in freshly deposited Sediments from river Mingao, main tributary to the municipal lake of Yaoundé (Cameroun).

[17] El-Rayis, A. O et M. A. H. Saad (1985). Concentration of $\mathrm{Cu}$, $\mathrm{Cd}, \mathrm{Zn}, \mathrm{Fe}$ and $\mathrm{Mn}$ in the Nile river water and its contribution to the Mediterranean. Journ. Etud. Pollut. CIESM, 7: 45-52.

[18] Fatima-Zohra; Afri-Mehennaoui; Leila Salhi; Naziha Zerief et Smaïl Mehennaoui (2009). Niveau de contamination par les éléments traces (ETM), des sédiments des oueds Rhumel et Sakiel Roum, dans les zones industrielles et à la Constantine (Algérie). Colloque international Environnement et transport rencontrés dans les contextes différents. Ghardaïa Algérie, 1618 février 2009. Actes. Enp ed Alger, p.181-187.

[19] Greichus Y. A., Greichius A., Amman B. A., Call D. J., Hamman C. D., et Potts R. M. (1977). Insecticides, polychlorinated biphenyls and metals in African lake ecosystems. Hartbeespoort Dam, Transval and voelvlei Dam, Cape Province, Republic of South Africa. Arch. Environmental Constam. Toxicology. 6: 371-83.

[20] Halima Ben Bouih, H. Nassal, M. Leblans et A. Srhiri (2004). Contaminations des métaux traces des sédiments du Lac Fouarates (Maroc).

[21] Hissein A. A., Gamga R.,Tchadanaye N. M. (2015) Int. Bio. Chem. Sc. 9 (3) pp.1654-1664).

[22] Jean Rodier (2009). The analysis of water (water, waste water, sea water), 9th edition, Dunod, Paris, 1383p.

[23] Jondreville C., Revy P., Jaffrezic A. Dourmad J. (2002). The copper in the diet of pork, oligo-element essence factor of growth and potential risk to man and the environment.

[24] K. M. Mohinddin, H. M. Zakir, K. Otomo, Sharmin, N. Shikazono (2010). Geochemical distribution of trace metal pollution in water and sediments of an urbain river, University Yokohana au Japon.

[25] Kakulu S. E., Osibanjo \& S.O. Ajayi (1978). Trace metals content of fish of the Niger delta area of Nigeria. Environmental.J. chem. soc. Nigeria.13: 9-15.

[26] Karaku S. \& Gey H. (2006). Analysis of the concentrations of certain heavy metals (iron, copper, zinc, chromium, cobalt, cadmium) in the flesh of yellow fish of the Caucasus (C poeta Capoeta Guldensta edt, 1972) fishing in the river of Kars en Turquie. Review Med. Vet. 157.11.551-556.

[27] Kemka N., Njine T., Niyitegeka D., Zebazé T. S. H., Nola N., Djouikom E., Ajigah G., Fotso S. M. \&Compére P. (2002). Eutrophication of the Yaoundé municipal lake (Cameroun) and cyanobacteria proliferation.

[28] Kayalto Barnabas (2009). Contribution to the assessment of contamination by heavy metals of three species of fish, sediments and the waters of Lake Chad. Memory of D. E. A. University of N'Gaoundéré, $82 p$.

[29] Maigo H., Marie J., Morand P. (2007). Avenir du fleuve Niger. IRD, 103p.

[30] Makhoukh M., M. Sbaa, A. Berrabou, M. Vancloster (2011). Contribution to the superficial waters physicochemical study of the Wadimonkouya (Morocco Oriental). Larhyss Journal, ISSN 1112-3680, $n^{\circ} 09$, pp 149-169.

[31] Ministère de la santé et des solidarités (2007). Decree, orders, circulars. Official Journal of the French Republic, 9 p.

[32] Monkolo J., Laraque A., Olivry J. C., Briquet J. P. (1993). Transport solution and suspension by the Congo (Zaire) River and its main tributaries of the right bank. Hydrologycal Sciences. vol 38(2,4): 133-145.

[33] Myrline Mompoint \& Kettly Theleys (2004). Assessment of the ecological dangers generated by urban effluents on the ecosystem of the Bay of Port - au- Prince; first methodological approach.

[34] Ndep R. (2002). Pollution physicochemical and microbiological a hydro system in urban areas; case of the Abiergue (Yaoundé II). Memory MASTER of environmental science. University of Yaoundé I.

[35] Ngaram Nabatingar (2011). Contribution to the "analytical study of pollutants in the (in particular types of heavy metals) in the waters of the Chari River on its journey of the city of N'Djamena in Chad. Thesis of the University Claude Bernard Lyon I. 163p.

[36] Raymond A. W. and Okieimen, F. E. (2011). Heavy Metals in Contaminated Soils: A Review of Sources, Chemistry, Risks and Best Available Strategies for Remediation; ISRN Ecology; 20p.

[37] Rizet, M. et Cognet, L. (1985). The quality of drinking water, new standards, sophisticated Analyses. News chimique, $25 \mathrm{p}$.

[38] Rodier Jean, Bernard Leguebe, Nicole Merket, et Coll (2009). The analysis of water, 9e edition. Dunod. Paris.

[39] Salomons, W. et U. Forstner (1984). Metals in the hydroxyl. Berlin, Spinger, 349p. 
[40] Saad, M. A. Fahmy (1995). Occurrence of some heavy metals in surfical sediment from the Damietta estuary of the Nile. Journ. Etud pollulCIESM,vol (7): 405-7.

[41] Samira A., Mohamed El. H. \& Marc L. (2002). Lead, copper, iron, manganese in the Sebou basin; source of contribution and impact on the quality of surface waters. Water qual.. RES J. Canada flight (4): p.773-784.

[42] Schéma Directeur de l'Eau et de l'Assainissement, Tchad (2003). HCNE-MEE-PNUD-DAES, p. 260.

[43] Tchadanaye N. M., Noumi G. B., Paloumi B., (2016). Pollution of the Chari River in the Slaughterhouse Farcha
(N'djamena) in Chad. American Journal of Environmental Protection 5 (3).

[44] Tchoroun M., Noumi G. B. et Tchadanaye N. M. (2015). Heavy Metals Pollution Level in water, Fish and Sediments from the Logone River within Moundou City (Chad). International Journal of Environmental Monotoring and Analysis Vol.3, No5 pp275-281.

[45] Wandiga, S. O, \& J. M, Onyari (1987). The concentration of heavy metal: $\mathrm{Mn}, \mathrm{Fe}, \mathrm{Cu}, \mathrm{Zn}, \mathrm{Cd}$ and $\mathrm{Pb}$ in sediment and fish from the Winam Gulf of Lake Victoria and fish bought in Mombasa town markets. Kenya J. sci, 8: 5-18. 